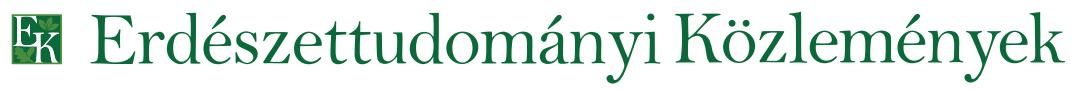

11. évfolyam 1-2. szám 2021

DOI: https://doi.org/10.17164/EK.2021.006

95-114. oldal

\section{A MAGYARORSZÁGI HOSSZÚ LEJÁRATÚ ERDÉSZETI TARTAMKÍSÉRLETI HÁLÓZAT FENNTARTÁSÁNAK KORSZERÜ IRÁNYELVEI, ADATFELDOLGOZÁSI MÓDSZEREI ÉS LEGFONTOSABB EREDMÉNYEI}

\author{
Kollár Tamás ${ }^{1}$ és Borovics Attila ${ }^{2}$ \\ ${ }^{1}$ Soproni Egyetem - Erdészeti Tudományos Intézet, Ökológiai és Erdőművelési Osztály \\ ${ }^{2}$ Soproni Egyetem - Erdészeti Tudományos Intézet, Nemesitési Osztály
}

\begin{abstract}
Kivonat
A magyarországi hosszú lejáratú erdészeti tartamkísérleti hálózatot 1962-ben alapították Solymos Rezső irányításával, azóta az Erdészeti Tudományos Intézet folyamatosan fenntartja a hálózatot és vizsgálja adatait. A hálózat fenntartásának alapvető céljai változatlanok annak megalapitása óta. Elsődleges célja, hogy megfelelő bázist nyújtson az erdőművelési és fatermési kutatásoknak Magyarországon. A kísérleti hálózat bükk (Fagus sylvatica), kocsánytalan tölgy (Quercus petraea), cser (Quercus cerris), kocsányos tölgy (Quercus robur), gyertyán (Carpinus betulus), magas kőris (Fraxinus excelsior), erdei fenyő (Pinus sylvestris), fekete fenyő (Pinus nigra) és lucfenyő (Picea abies) fafajokból álló erdőállományokban található. Több mint 3000 parcella, közel 11000 felvételi jegyzőkönyvének adataival rendelkezünk (átmérő, magasság, osztályozás), melyekböl 6600 feletti jegyzőkönyv digitálisan hozzáférhető és felhasználható. Körülbelül 1200 parcella jelenleg is élő mintaterület. Összefoglaljuk a kísérleti parcellák kitüzésének, felvételének és fenntartásának részletes módszertanát, és a tartamkísérletek eredményei alapján eddig készült legfontosabb publikációkat. Ezek közül kiemelkedőek a fafajonként készült országos fatermési táblák és erdőnevelési modellek, amelyeket az újabb adatok birtokában szükséges megújítani.

Kulcsszavak: hosszú lejáratú erdészeti tartamkísérletek, kísérleti irányelvek, fatermési táblák, erdőnevelés modellek, fatermési adatbázis, ökológiai kutatások
\end{abstract}

\section{THE UPDATED METHODOLOGICAL DIRECTIVES OF DATA PROCESSING AND MAINTAINANCE OF THE HUNGARIAN LONG TERM FORESTRY EXPERIMENTAL NETWORK, AND ITS MOST IMPORTANT RESULTS}

\begin{abstract}
The Hungarian long-term forestry experiment network was established in 1962, with the lead of Rezsö Solymos, The Forest Research Institute has been running the network continuously since that time and its data are under research. The basic objectives of the network are unaltered since the establishment. The primary aim was to create a suitable basis for silvicultural and forest yield research in Hungary. The experiment plots take place in forest stands of common beech (Fagus sylvatica), sessile oak (Quercus petraea), Turkey oak (Quercus cerris), pedunculated oak (Quercus robur), hornbeam (Carpinus betulus), common ash (Fraxinus excelsior), Scots pine (Pinus sylvestris), black pine (Pinus nigra) and Norway
\end{abstract}


spruce (Picea abies). More than 3000 plots, about 11000 survey reports (diameter, height, classification) are available, from which more than 6600 survey reports are digitally accessible. About 1200 plots are still monitored. The detailed methods of alignment, measurement and maintenance of the experimental plots and the most important publications of the long-term experiments are summarized. From these, the national forest yield tables and silvicultural treatment models are significant, but with the possession of new data, reformation is necessary.

Keywords: long-term forestry experiments, experiment directives, yield tables, silvicultural treatment models, yield database, ecological studies

\section{BEVEZETÉS}

A XX. század közepére egyre sürgetőbbé vált az igény olyan szakmai útmutatásokra, amely az értékes tapasztalatokon túl számszerü eligazítást adnak az erdőműveléssel és az erdők fatermésének meghatározásával foglalkozó szakember számára.

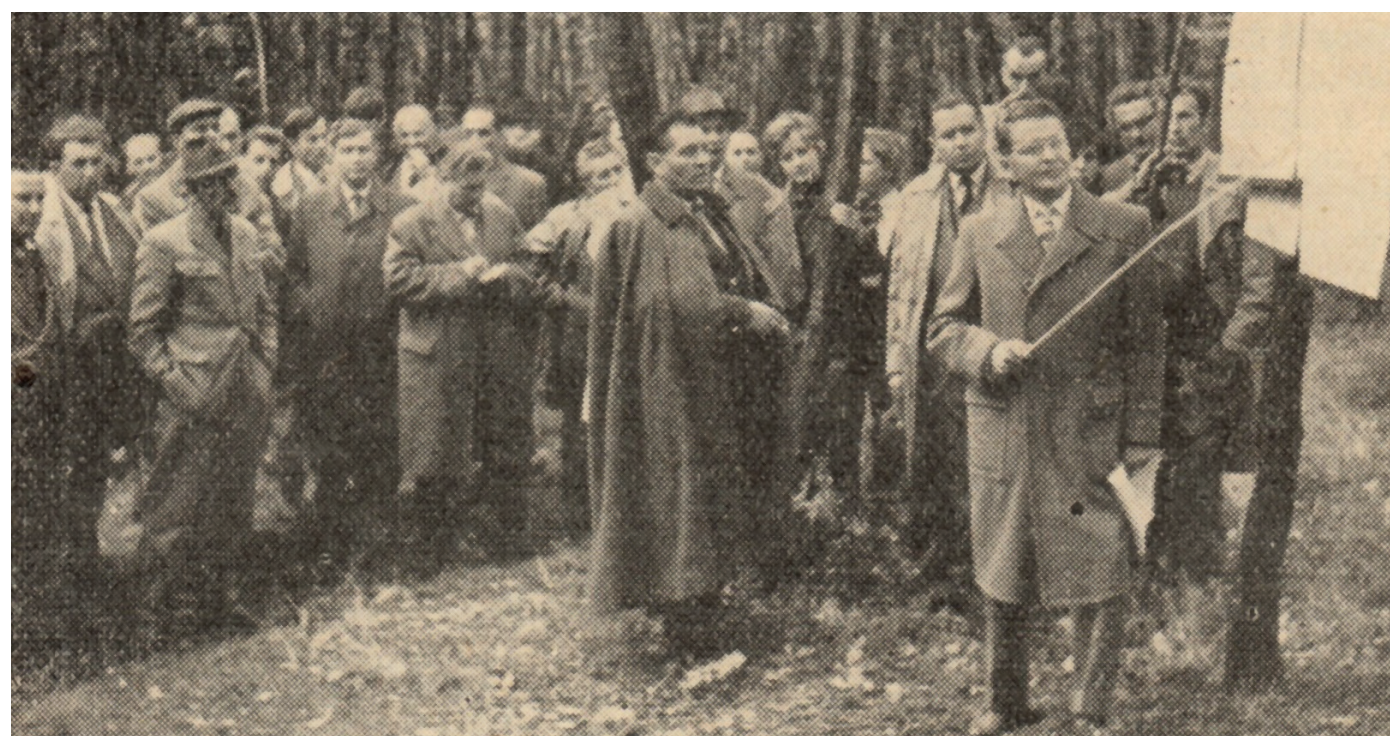

1. ábra: Dr. Solymos Rezső ismerteti a Lajos-forrási kísérletet. 1962.10.07. (Jérőme 1963)

Figure 1: Dr. Rezső Solymos is reviwing the experiment at Lajos-spring. 07.10.1962. (Jérőme 1963)

Birck Oszkár, Kiss Rezső, Márkus László, Solymos Rezső és Tallós Pál együttműködésével indult el a máig ható gondolat: „Az erdőnevelési és fatermési kutatásokban csak hosszú ideig tartó, jól szervezett és megalapozott munkával lehet eredményt elérni. Szükséges, hogy ezek a kutatások egységes alapelvek szerint folyjanak az ország területén. E célra kísérleti területeket kell kijelölni, melyeken azonos módon végzik a kitüzést, a felvételeket és a kezelést." Birck Oszkár és kollégái ezekkel a mondatokkal vezették be a hosszúlejáratú erdőnevelési és faterméstani kísérleti területek kitűzésének, felvételének és fenntartásának irányelveit összefoglaló cikküket (Birck et al 1962). Három évtized után Béky Albert és munkatársai összefoglalták a hosszúlejáratú erdőnevelési és faterméstani kísérleti területek létesítésének, felvételének és fenntartásának továbbfejlesztett irányelveit (Béky et al 1993). Azóta újabb három évtized elteltével célszerü összefoglalni az erdészeti tartamkísérletek elmúlt hat évtizedének korábbi eredményeit, a kísérlet módszertanában bekövetkezett változásokat, az adatbázis jelenlegi rendszerét, feldolgozási módszereit és jövőbeli terveit is. 


\section{ELŐZMÉNYEK}

Kaán Károly már 1905-ben felvetette az erdőnevelési kísérleti területek létrehozásának szükségszerüségét, azonban az akkori erdészeti kísérleti ügy még nem volt alkalmas ennek végrehajtására (Kaán 1905). Az 1900as évek elejétől ugyan létesültek Magyarországon erdőnevelési kísérletek, melyeket olyan neves erdészeti személyiségek kezeltek és vizsgáltak, mint Vadas Jenő, Czillinger János, Roth Gyula, Fekete Zoltán és Rónai György, azonban ezek a kísérletek jellemzően egyedi módszertannal létesültek (Birck et al 1962). Több előző tervezet nyomán Majer Antal tett javaslatot erdőnevelési kísérletek kialakítására és vizsgálati módszerére (Majer 1957), végül az 1962-ben megjelent útmutató tekinthető az erdészeti tartamkísérleti hálózat alapjául szolgáló módszertannak (Birck et al 1962).

\section{CÉLOK ÉS IRÁNYELVEK}

A kísérletek irányelveit - melyek egységes keretbe foglalták az Erdészeti Tudományos Intézetben Dr. Solymos Rezső vezetésével újjáalakított Erdőművelési és Fatermési Osztály későbbi munkáját; 1961. december 4-én vitatták meg a Magyar Tudományos Akadémián. A kutatócsoport megalakításában és a kísérleti hálózat fenntartásában kiemelkedő szerep hárult Solymos Rezsőre, aki osztályvezetőként, illetve később akadémikusként kiharcolta eme hatalmas nagyságrendű kutatás megkezdését és évtizedekig való fenntartását (Solymos 2013ab).

A tartamkísérleti hálózat fenntartásának alapvető céljai kibővültek a hálózat megalapítása óta. Elsődleges célja az volt, hogy megfelelő bázist nyújtson az erdőművelési és fatermési kutatásoknak. Ezek a célok a későbbiekben tovább bővültek az újabb kutatási igények és társadalmi elvárások megjelenésével az azóta eltelt évtizedekben (Birck et al 1962, Béky et al 1993).

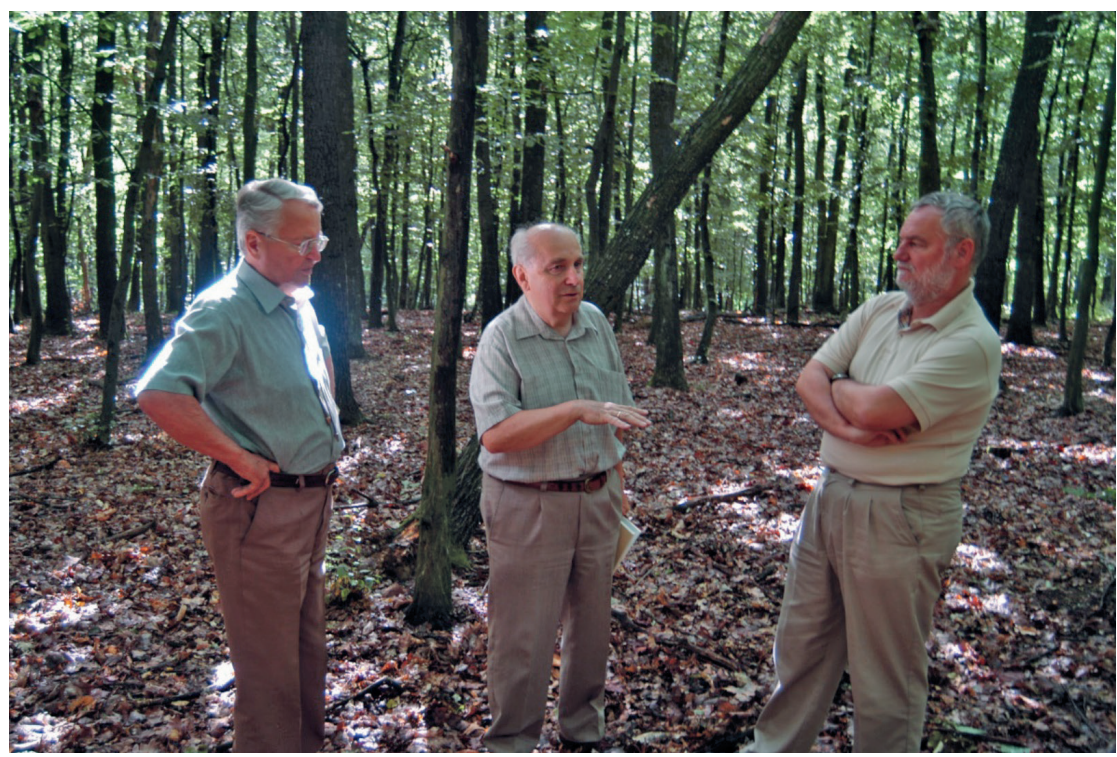

2. ábra: Solymos Rezső és Béky Albert mutatják be a tartamkísérleti hálózatot Németh Tamásnak, az akadémia akkori fötitkárának, Bejcgyertyános, tölgy erdőnevelési sor, 2008.07.04.

Figure 2: Rezső Solymos and Albert Béky are presenting the long-term forestry experiment network to Tamás Németh, the former secretary general of the academy, Bejcgyertyános, oak silvicultural treatment raw, 04.07.2008. 
Az erdőnevelési és faterméstani kutatások érdekében létesített kísérleti területek a következő célok megvalósítását szolgálják:

- Az ország főbb erdőtípusaiban a fatermesztési célú állományok nevelési irányelveinek meghatározása.

- Milyen időpontban kell elkezdeni az egyes nevelővágásokat?

- Milyen a nevelővágások célszerű erélye és mennyi legyen a visszatérés ideje?

- Milyen hatással vannak a nevelővágások az összes fatermésre?

- Az erdők természetes felújulásának lehetőségei és módjai.

- Állományszerkezeti és fatermési mutatók vizsgálata, mely kiterjed:

- a faállományok külső szerkezeti tényezőire (záródás, sürűség, elegyarány),

- a faállományok belső szerkezeti tényezőire (alakszám, körlap stb.),

○ egyes fák fatermésére és

○ faállományok fatermésére (fatömeg és fatermési táblák szerkesztése).

\section{A TARTAMKÍSÉRLETI HÁLÓZAT}

A kísérleti hálózat lefedi a magyarországi, gazdasági szempontból legfontosabb fafajok kor- és termőhelyi spektrumát, ezáltal részletes adatokat szolgáltat a fatermési kutatásokhoz. A jelenlegi kutatási struktúrában nem foglalkozunk a nemesnyárak, illetve az akác faterméstani kutatásával, mivel ezeket célzottan és a fajtaelőállító nemesítéssel összekötve kiemelten vizsgálják az ERTI-n belül. Egyes fafajok, mint a lucfenyő (Picea abies) (LF) és feketefenyő (Pinus nigra) (FF) a kiinduló állapothoz képest jelentősen veszítettek erdészeti jelentőségükből, ezért ezek feldolgozására jelenleg kisebb hangsúlyt tudunk fektetni.

A kísérleti hálózat az alábbi főfafajú állományokra nézve rendelkezik részletes fatermési adatbázissal:

- bükk (Fagus sylvatica) (B)

- kocsánytalan tölgy (Quercus petraea) (KTT)

- kocsányos tölgy (Quercus robur) (KST)

- $\operatorname{cser}$ (Quercus cerris) (CS)

- gyertyán (Carpinus betulus) (GY)

- magas kőris (Fraxinus excelsior) (MK)

- erdeifenyő (Pinus sylvestris) (EF)

E fafajok korábbi jegyzőkönyveinek digitalizálása a lombos fafajok esetében befejeződött. Az élő parcellák felvételezése folyamatos. A jelenlegi adatbázisban az 1. táblázatban megadott parcellák állnak rendelkezésre.

1. táblázat: A magyarországi erdészeti tartamkísérleti hálózat parcelláinak mennyiségi összefoglalása

Table 1: The quantitative summary of hungarian long term forestry experimental network plots

\begin{tabular}{|l|r|r|r|r|r|r|r|r|r|c|}
\hline \multicolumn{1}{|c|}{ Fafaj csoport } & \multicolumn{1}{|c|}{ B } & \multicolumn{1}{|c|}{ KTT } & \multicolumn{1}{c|}{ CS } & \multicolumn{1}{|c|}{ KST } & GY & MK & EF & FF* $^{*}$ & LF $^{* *}$ & Összesen \\
\hline Parcellák száma & 383 & 258 & 373 & 255 & 118 & 148 & 961 & 410 & 116 & 3022 \\
\hline Összes adat & 1908 & 1421 & 984 & 1132 & 505 & 328 & 3251 & 1151 & 229 & 10909 \\
\hline Átlagos visszatérések száma & 5 & 6 & 3 & 4 & 4 & 2 & 3 & 3 & 2 & 4 \\
\hline Visszatérések átlagos ideje (év) & 7 & 6 & 10 & 7 & 6 & 10 & 7 & 6 & 8 & 7 \\
\hline \multirow{2}{*}{ Digitalizált és feldolgozott } & 1518 & 1249 & 923 & 1009 & 460 & 249 & 681 & 401 & 149 & 6639 \\
\cline { 2 - 11 } & $80 \%$ & $88 \%$ & $94 \%$ & $89 \%$ & $91 \%$ & $76 \%$ & $21 \%$ & $35 \%$ & $65 \%$ & $61 \%$ \\
\hline
\end{tabular}

* az eredeti jegyzőkönyvek tárolási helye nem ismert, de a részletes regiszterek elérhetőek

** kizárólag digitális anyagok lelhetőek fel, regiszterek nincsenek meg, az eredeti jegyzőkönyvek tárolási helye nem ismert 
A fent említett fafajokból jelenleg 3000 feletti parcella (kb. 500 ha mintaterület) közel 11000 jegyzőkönyvének adataival rendelkezünk, egyes esetekben akár 60 éves vizsgálati időszakot is lefedve. Ezek közül jelenleg több mint 6600 jegyzőkönyv digitálisan hozzáférhető és felhasználható. Fontos megjegyezni, hogy ezek közül már csupán kb. 1200 parcella (kb. 200 ha) lehet jelenleg is élő mintaterület, a többi parcella elérte vágáskorát, vagy egyéb okokból álltak le a kísérletek.

\section{A kísérleti parcellák típusai}

Fatermési parcellák, melyek célja, hogy lefedjék a magyarországi fafajok kor és termőhelyi spektrumát. Ezeket a parcellákat üzemi gyérítési elvek alapján kezelik, tehát az országos és helyi gyérítési elveket veszi figyelembe a gazdálkodó, a kísérlet nem befolyásolja az itt végzett erdőművelési munkákat. Minden hasonló módszertannal felvételezett kísérleti parcella fatermési parcellaként is felhasználható, amennyiben lombozata zárt, kora ismert, faállománya többnyire egy főfafajból áll, és felvételezése folyamatos (pl. kísérleti sorok, intenzív monitoring parcellák, egyéb kitüzések).

Erdőnevelési kísérleti sorok esetében azonos termőhelyen és korban (általában egy erdőrészleten belül) több (minimum 3) parcella található. Ezekben a sorokban található kontroll terület, ahol tiltott a fakitermelés, egy üzemi gyérítésű parcella, és több különböző mértékben gyérített parcella, melyeken a különböző erélyü nevelővágásoknak a növedék alakulására gyakorolt hatása vizsgálható. A kísérletek időtartama miatt sajnálatos módon a kontroll parcellák ritkán tekinthetőek teljesen beavatkozástól mentesnek, jellemzőbb, hogy hosszú távon, mint a legkisebb gyéritési erélyü parcellaként vizsgálhatóak.
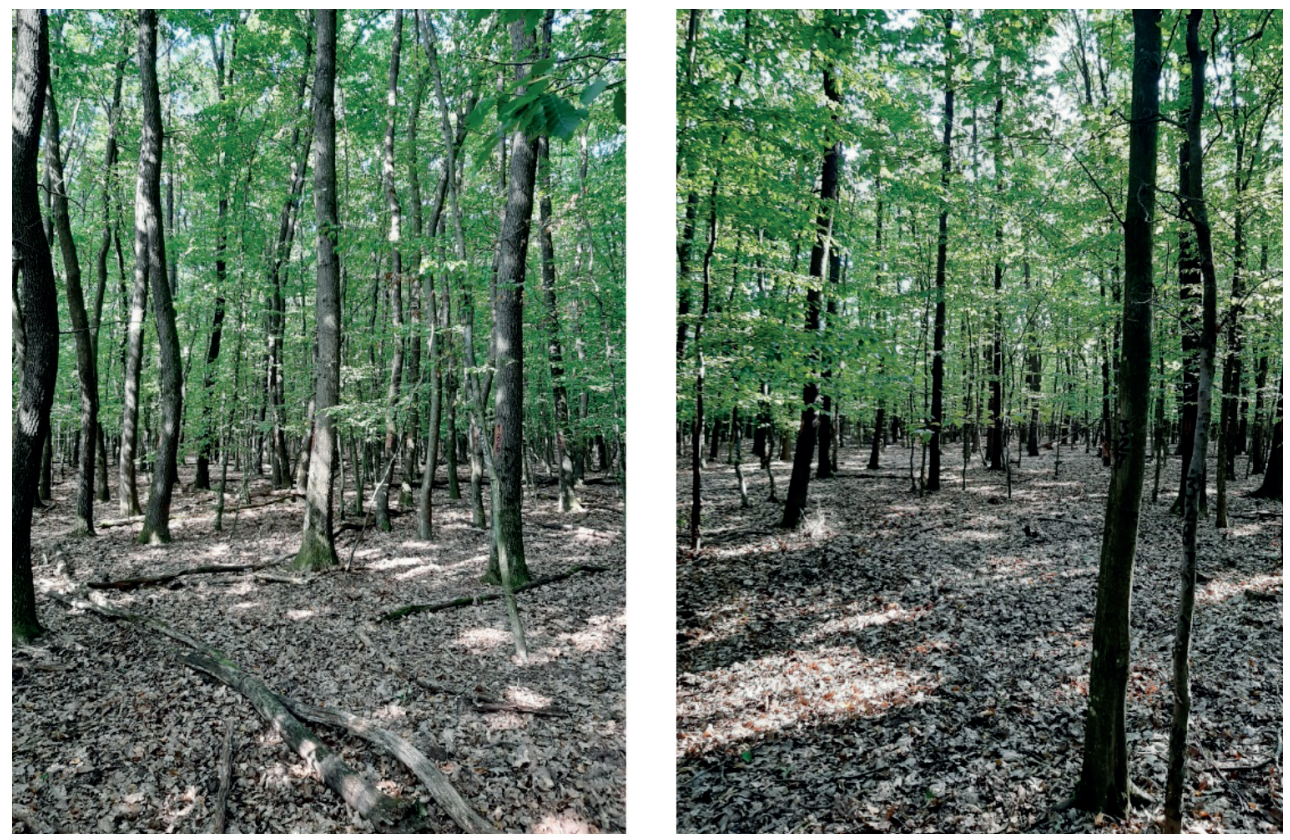

3. ábra: kontroll és erősen gyéritett parcella egy 66 éves bejcgyertyánosi gyertyános-kocsánytalan tölgyes erdőnevelési sorban, 2021.08.12.

Figure 3: control and intensely thinned plots at a 66 year old hornbeam-sessile oak silvicultural treatment raw in Bejcgyertyános, 12.08.2021. 
Az erdőnevelési kísérleti sorok speciális altípusai az alábbiak:

Ültetési hálózati kísérleteket leginkább az ültetvényszerű fafajok (elsősorban erdei-, fekete- és lucfenyő, illetve akác és nemes nyárak) esetében létesítettek nagyszámú parcellával annak vizsgálatára, hogy a különböző ültetési hálózatokban különböző eréllyel végzett nevelővágások hatására miként alakul az adott faállomány növedéke, illetve fatermése.

Fafaj összehasonlító sorok esetében azonos termöhelyen különböző fafajokkal létesítették az erdőnevelési sorokat vagy ültetési hálózati kísérleteket. Térben távolabbi, de hasonló termőhelyen álló, hasonló korú, de különböző fafajú állományok is vizsgálhatóak.

Technológiai sorok esetében valamely erdőnevelési vagy fakitermelési technológia kipróbálására állítottak be erdőnevelési sorokat. Ide tartoznak a tisztítási kísérletek is.

A kísérleti területek egymásra épülve építik fel az országos erdészeti tartamkísérleti hálózatot. Egy kutatási sor adott főfafaj esetében tartalmazza a változatos korú és termőhelyű parcellák és kísérleti sorok összességét, melyek így elméletileg lefedik az adott fafaj országos magassági szórásmezejét.

\section{Kísérleti parcellák kitűzésének, felvételének és fenntartásának módszertana}

A kísérleti parcellák területe változó. A kísérletek kezdetén az $50 \mathrm{~m} \times 50 \mathrm{~m}$ oldalhosszúságú derékszögü négyzet kísérleti területek kitüzése volt a legjellemzőbb, később a jellemző méretet 33,3 m×33,3 m-re csökkentették költséghatékonysági megfontolásokból, azonban ennél kisebb és nagyobb parcellák is kerültek kitüzésre. A terület mérete függ az állomány korától a kitüzés idején, vagy egyéb szempontoktól is, mint pl. a terepadottságok vagy elegyes állomány fafaj szerkezete. A parcella alakja is eltérhet a szabályos négyzettől, amennyiben azt az erdőrészlet területe, alakja és állományviszonyai indokolják. Kísérleteztek kör alakú parcellákkal is, melyek azonban nem váltak elfogadottá (Kiss 1964). Nagy egyedszámú fiatal állományokban általában kisebb, a kis egyedszámú, idős állományban általában nagyobb parcellákat tűztek ki. A parcellákhoz elméletileg védősávok is tartoztak (kísérleti parcella + védősáv = kísérleti tábla), ahol kísérleti felvételezés már nem folyt, azonban a gyérítések módját a kísérlethez kellett igazítani. Ezek a védősávok a későbbi kitüzéseknél már hiányoztak, és a parcellák közvetlenül egymás mellé is kerülhettek. A parcellák sarokpontjait kezdetben szabványosan meghatározott, földbe ásott oszloppal és határ halommal állandósították. llyen kutatástörténeti emlékeket ritkán még találni a mintaterületeken. Később a kitüzött sarokponthoz legközelebb eső parcellán kívüli fa dupla, kék körgyűrűvel való festése vált általánossá. A parcellák széleit a parcellán kívül eső egy sor fának a befelé nőző oldalán történő kék vonallal festették meg. A védősávokat korábban világoskék festéssel jelölték, azonban ezeket már nem festjük újra. A parcella helyét vázrajzon szükséges jelölni. A parcella hozzávetőleges helyének GPS koordinátáját is rögzítjük. Terveink szerint az élő parcellák helyének geodéziai pontosságú bemérése is megtörténhet a közeljövőben, mellyel lehetőséget teremthetünk a térinformatikai és faterméstani kutatások összekapcsolására.

A parcellában található faegyedeket sorszámmal és a mérési hely megjelölésével kell ellátni. A mellmagassági átmérő mérési helyét „T” alakú vonallal jelöljük, 1,3 méter magasságban (mellmagasság), fekete festéssel. Erre a jelre helyezve, majd pedig 90 fokkal elfordulva kell az átmérőméréseket végrehajtani. A sorszám festése a mérési jel felett található, szintén fekete festéssel. Sok helyen még a korábban alkalmazott fehér festés is látszik a fákon. Barázdált kérgű fafajok esetében vonókéssel alakítjuk ki a sorszám festéséhez az úgynevezett tükröt a fatest megsértése nélkül. A fák sorszámozása a parcella egyik sarkából kiindulva fasoronként vagy pár méter széles sávonként kígyóvonalban történik. Minden faegyed sorszámot kap. A parcella szélét jelző festéseket, sorszámozást és mellmagassági átmérő mérés helyét az újrafelvételezésekkor szükséges megújítani, amennyiben azok annyira elkoptak, elhalványodtak, hogy a jövőben soron következő újabb felvételkor már nem lesznek megfelelően láthatóak. A parcellák felvételezésének visszatérési ideje a 
kutatási terv szerint 5 év. A parcellák faegyedeinek pontos bemérése a jelentős munkaráfordítás miatt nem, vagy csak kivételes esetben történt meg. A jövőben Field Map rendszerű vagy lézer szkennelésen alapuló technológiával a parcellák felvételezése kibővithető részletes állománytérkép készítésével is.

A terepi felvételezés gyakorlata az elmúlt évtizedek tapasztalatait felhasználva állandósult. 2-4 fő dolgozik a parcellában, hatékonyan elosztva a szükséges munkafolyamatokat. A felvételezések ideje jellemzően a vegetációs időszakon kívüli idő, ősztől tavaszig. A legfontosabb felvételezendő adatok az alábbiak:

- Mellmagassági átmérő mérése $\left(\mathrm{d}_{1}, \mathrm{~d}_{2}\right)$ két irányból, milliméter pontossággal történik, átlaló használatával. Fahibák esetén a fahiba alatt, felett vagy oldalt fordítva történnek a mérések, hogy a faegyedre leginkább jellemző átmérő értéket kapjuk.

- Magasság mérés (h) fafajonként magassági görbe megszerkesztéséhez elegendő mennyiségben (megfelelő pontossághoz minimum 20-30 adat szükséges), deciméter pontossággal történik. Idősebb állományban, kis tőszámú parcellákban minden egészséges fa magasságát mérjük. Csúcstörött, vagy koronaszáradt fák magasságát nem mérjük.

- Minden faegyed magassági osztályozást (m.o.) kap. A magassági osztályozás nem a faállományt alkotó faegyedek abszolút magasságán alapul, hanem azok egymáshoz viszonyított relatív magasságán, szociális helyzetén.

○ 1. Kimagasló fák. A korona felülről teljesen, oldalról részben szabad. Kivételesen erősen fejlett korona, felső része kiemelkedik a faállomány felső szintjéből.

- 2. Uralkodó fák. A korona felülröl teljesen szabad, nagy részét közvetlenül éri a fény. Az uralkodó fák koronája alkotja a faállomány felső koronaszintjét.

○ 3. Közbeszorult fák. Csak a csúcs szabad, a csúcsot még közvetlenül éri a fény, oldalról a magasabb szomszédos fakoronák erős nyomása alatt áll.

○ 4. Alászorult fák. A koronacsúcs sem szabad, nem éri közvetlenül a fény. A szomszédos fák koronája alá szorult, de még a felső koronaszinthez tartoznak.

○ 5-8. A második koronaszint fái. Kétszintü faállományok esetén minősíthető, pl. újulat vagy egy idősebb faállomány alatt felverődött elegy esetén.

- Minden faegyed erdőnevelési osztályozást (n.o.) kap:

○ 1. Javafák, vagy korábban „V” fák, a faállományban hosszú távon megőrzendő, legszebb törzsalakú és minőségü faegyedek. Általában 1-2. magasság osztályú faegyedek.

○ 2. Segítő fák, az állomány záródását és a javafák törzsárnyalását segítik. Gyérítéskor kivágandó fákká válhatnak. Általában 2-3. magassági osztályú faegyedek, vagy a második lombkorona szint egyedei.

○ 3. Kivágandó fák, általában rossz törzsalakú, gyenge fejlődésü fák, esetleg állományidegen fafajok, melyeket a soron következő gyérítéskor célszerű eltávolítani. Általában 3-4. magassági osztályú faegyedek.

○ 4. Száradék. Azok a fák, amelyek a két felvétel között eltelt időszakban kiszáradtak (elpusztultak) és álló vagy fekvő holtfaként megtalálhatóak a parcellában, vagy fakitermelés során eltüntek az állományból. Az utolsó élő átmérő és magasság adatukkal szerepelnek a feldolgozott jegyzőkönyvekben.

A fák osztályozása nagyban függ a jegyzőkönyvvezető tapasztalatától, szokásaitól is, ezért ezen adatok felhasználása komoly megfontolásokat igényel.

A korábbi tervek között szerepeltek további vizsgálatok is (növőtér meghatározása, koronahosszúsági-, koronaátmérőarány-, levélfelületnagysági osztályozás, kombinációs törzsminősítés, fejlődési állapot meghatározása), ezek azonban nem váltak gyakorlattá.

A kísérletek kezdete óta papír alapú jegyzőkönyvvezetést alkalmazunk, mivel ez a leggyorsabb, illetve leginkább időjárás álló módszer. A ceruzával írt adatok a felvételezés során könnyen javíthatóak. Emellett 
az irattárban elhelyezett jegyzőkönyvek évtizedek multán is újra digitalizálhatóak. Az 1980-as években volt kísérlet terepi mikroszámítógép alkalmazására (Somogyi 1986, Somogyi 1987), azonban ez nem terjedt el, az akkor használt technológiák drágák voltak, és hamar elavultak. Digitális átlalók bevezetése a kísérleti parcellák felvételezésében nem vált be, mivel pontosságuk általában gyengébb (cm vagy méretcsoportos), illetve a sorszám, fafaj, magassági és nevelési osztályozási adatok bevitele, hibás adatok módositása nehézkes vagy nem megoldható, megjegyzések nem tehetőek.

A felvételezés végén fénykép készül a parcelláról, mely a jellemző állományképet mutatja. A digitális fényképezés megjelenése előtt ilyen fényképek csak ritkán készültek.

Terepi felvételezésnél a korábban előkészített jegyzőkönyv tartalmazza az utolsó felvételkor felvett adatokat, ezáltal segítséget nyújt az esetleges hibák felderitésére és kiküszöbölésére:

- Fafaj és sorszám hibák észrevétele jegyzőkönyvben vagy a fák festésén.

- Hibás átmérő vagy magasság adatok észrevétele.

- Adódhat hibás mérésből, félrehallásból, elírásból, digitalizálás során történő elgépelésből is, vagy akár két különböző sorszámú fa véletlen felcseréléséböl.

- Korábban nem felvételezett faegyedek megtalálása.

- Sajnálatos módon több korábban elegyetlen állományként leírt parcella felkeresésekor előfordult, hogy ott második lombkoronaszintü állományt (pl. EF vagy KTT állományban GY, hárs vagy egyéb második szint) vagy egyéb fafajú állományrészt (pl. KST állományokban kőris vagy nyár elegy) találtunk. Ilyen esetekben az újonnan talált fafajokat, faegyedeket a sorszámozásba kell illeszteni, és a korábbi jegyzőkönyveket a későbbiekben visszamenőlegesen javítani szükséges a megtalált fák becsült növekedési ütemével (például fatermési tábla alapján). Noha a módszer visszamenőlegesen nem ad tökéletes állapotleírást, az elegyarányokat javíthatja.

Az 1950-es évektől papír alapon tárolt adatok digitalizálásának igénye már az 1980-es években felmerült (Somogyi 1985), azonban sokáig nem vált általánossá. A felvételi jegyzőkönyvek nagy része ekkor még nem került korszerủ módon digitalizálásra, mivel a kezdetekben papír alapon, később lyukkártyákon (Márkus 1965), kezdetlegesebb számítógépeken zajlottak az adatrögzítések és feldolgozások.

Az 1990-es évektől a személyi számítógépek elterjedésével a digitalizáció felgyorsult és egyre nagyobb igény mutatkozott a korábban papír alapon tárolt adatok felhasználására. Ezt az igényt szolgálta ki a Veperdi Gábor által írt feldolgozó algoritmus Excel táblázatkezelő programra (Veperdi 1995). Ekkor lehetővé vált egy általános formátum létrehozása az adattárolásra és feldolgozásra, mely alapjaiban a mai napig használatban van az ERTI-ben az aktuális Excel verziókhoz frissítve. Ekkor még a fafajonként elosztott feladatok és adatok különálló kutatóknál összpontosultak.

2012 után az adatok korábban elkülönült tárolását és feldolgozását közös adatbázisrendszerrel oldották meg. A teljes kísérleti hálózat egy kutató irányítása alá került. A meglévő különálló digitális adatbázisokat egységesíteni kellett, könnyen szürhető, korszerű adatbázissá. A papír alapú regiszterek digitalizálása után átlátható könyvtárszerkezetbe rendszereztük a digitalizált felvételi adatlapokat. $A$ nem digitalizált jegyzőkönyveket lehetőség szerint regisztráltuk, és előkészítettük a folyamatos adatbevitelre, mely a mai napig tart (Kollár et al 2018). A digitális adatok archiválását heti rendszerességü mentések teszik lehetővé a kutató számítógépe és az intézeti szerver között. A papír alapú eredeti felvételi jegyzőkönyvek száraz, biztonságos helyen való tárolása megoldott.

\section{Az erdészeti tartamkísérleti adatrendszer felépítése}

Az eredeti jegyzőkönyveket, térképeket, egyéb kiegészítő információkat tartalmazó papír alapú mappák vagy spirálfüzetek az SOE ERTI Sárvári Kísérleti Állomásának irattáraiban találhatóak. Ezeket könyvtári 
rendszerhez hasonlóan, regiszterfüzetekben kezeljük, melyek fafajonként, törzskönyvi számokkal katalogizálva, felvételi dátum alapján tartalmazzák a mappákat és füzeteket, és ezek tárolási helyét.

A digitális adatbázis ezen adatokból épül fel az alábbiak szerint:

- Regiszter adatbázis tartalmazza a tartamkísérleti hálózatban valaha kitüzött parcellák adatait, és felvételi éveit, amennyiben tudomásunk van adatról. Ez az adatbázis könnyen szürhető főfafajra, törzskönyvi számra, termőhelyi adatokra, megyére, erdőrészletre, parcella típusra, felvételi évekre, megszünt vagy élő parcellákra és a feldolgozottság jelenlegi fokára is.

- Google Maps digitális térkép fedvényt készítettünk, mely tartalmazza a kísérleti területek hozzávetöleges helyét erdőrészlet vagy parcella szinten. Elsősorban a terepi tájékozódást segíti. A parcellák pontos bemérése szükséges lehet térinformatikai alkalmazáshoz a jövöben.

- Parcellánként Excel formátumban tartalmazza a digitalizált, hibaellenőrzött, feldolgozott jegyzőkönyveket digitális mappákban tárolva. Hibaellenörzés során ellenőrizzük, hogy

○ nincsenek-e fafaj hibák, tehát adott sorszámú faegyed fafaja nem változott-e meg, vagy egy felvétel során esetleg nem maradt-e ki, vagy felcserélődött sorszám miatt nem került-e rossz helyre egy adott faegyed.

- az egymást követő felvételek során egyes faegyedek átméröje és magassága nem csökkenhet, illetve nem lehetnek valószerütlenül nagy növekedések sem. Hiba esetén az adatok értelemszerü módositásával járunk el. Amennyiben több felvétel között a közbenső felvételnél nem rendelkezünk magassági adattal, interpolálással pótolhatjuk az adatot.

- amennyiben az adatok sorszámozás nélkül, átmérőcsoportosan vagy új sorszámozással kerültek felvételre, az átméröadatok csökkenő sorrendbe rendezésével tudjuk a faegyedek növekedési sorát kialakítani az egymás utáni vagy közbelső jegyzőkönyvekben, feltételezve, hogy a kisebb átmérőjü, alászorult fák tüntek el az állományból. Itt is alkalmazni kell az alap feltevést, miszerint egy faegyed átmérője nem csökkenhet és nem lehet túlzott sem a növekedés.

- Elöfeldolgozás során fafajonként számítjuk a Király-féle fatérfogat függvénnyel a faegyedek fatérfogatát felvételezett magasság (ha az nem áll rendelkezésre adott faegyedre, akkor magasság görbe alapján) és a két felvételezett átmérő átlagátmérője alapján. Korábban a Veperdi Gábor által készített paramétertáblát használtuk (Veperdi 1995), melyet azóta felváltott a legújabb függvényesített fatömeg tábla paraméterkészlete (Sopp et al 2013). Az így kapott adatok eltéréseket mutattak, ezért minden korábban feldolgozott adatot újraszámítottunk. A faegyedenkénti fatérfogat számítás után újra ellenőrizzük az adatokat, hogy fatérfogat csökkenés se alakuljon ki faegyedenként. Ez a famagasság görbék metszése esetén alakulhat ki, amikor a görbe alábecsli a korábbi felvételi magasságot. Ilyen esetben az adott faegyed utolsó magassági adatának használatával korrigáljuk a számítást.

- Az így ellenörzött és elő feldolgozott adatok faállományszerkezeti feldolgozása egy újabb fájlban történik, mely adatai az eredmény adatbázisba kerülnek.

- Az eredmény adatbázis tartalmazza a teljes tartamkísérleti anyag állományszerkezeti jellemzöit, melyek így felhasználhatóak a kutatásokhoz. Az állományszerkezeti adatok az alábbiakat tartalmazzák adott parcella adott évi jegyzőkönyvére vonatkoztatva:

- Felvétel ideje és vonatkozási év, mely július 1. után megegyezik a felvétel évével, június 30-ig pedig az előző évvel. Nyáron jellemzően nem történik állomány felvételezés.

- A parcella kora (év), mely a parcella kitüzésekor lett megállapítva üzemtervi adatok vagy évgyürüszámlálás alapján. Újrafelvételezéskor az eltelt vegetációs időszakok számával növelve történik a korosbítás.

- Esetleges záródáshiány (\%). Ez az adat jellemzően hiányzik a korábbi jegyzőkönyvekböl, és az állományokat $100 \%$ záródásúnak tekintik. Idős állományok esetében - ahol a felújitó vágások 
elkezdődtek - visszaeshet a záródás, ezért azt a terepen szembecsléssel állapítjuk meg, illetve amennyiben nincs záródás adat, a kitermelt fatérfogat alapján becslést alkalmazunk.

- Fafajokra, illetve összes fafajra vetítve az állományt három fő részre bontjuk.

- Főállomány, mely összegzi az 1-es (javafák) és 2-es (segitő fák) nevelés osztályozású faegyedeket.

- „Elméleti” mellékállomány, mely a 3-as nevelési osztályozású, kivágandó fákat összegzi. Az így osztályozott faegyedeket a visszatéréses felvételek tanulsága szerint nem mindig távolítják el az állományból.

- Egészállomány a fö- és mellékállomány összessége. Mivel az adott felvétel összes élő faegyedét tartalmazza, nevezhetjük Élöállománynak is.

- Száradék a faállomány azon része, mely a parcellában holtfaként megjelent az előző felvétel óta. Ide kerülnek a kitermelésre került faegyedek is utolsó élő adatukkal, 4-es nevelési osztállyal. „Valós” mellékállománynak is nevezhetjük. Sajnálatos módon a valódi holtfa, és a kitermelt állományrész nem különíthető el. Ehhez további osztályozási kategória lett volna szükséges.

- A számított faállományszerkezeti jellemzők az alábbiak:

- Főfafaj felsőmagassága $\left(H_{f}\right)(m)$ : a hektáronkénti 100 legvastagabb fa magasságának körlappal súlyozott átlaga.

- Átlagmagasság $\left(\mathrm{H}_{\mathrm{g}}\right)(\mathrm{m})$ : az egyes törzsek magasságának körlappal súlyozott átlaga, $H_{g}=\frac{g_{1} \cdot h_{1}+g_{2} \cdot h_{2}+\ldots+g_{n} \cdot h_{n}}{G}$.

- Átlagátmérő $\left(D_{g}\right)(\mathrm{cm})$ : az egyes törzsek átmérőinek átlaga, kiszámítása a hektáronkénti körlapösszeg alapján történik,

$D_{g}=\sqrt{\frac{4 \cdot G}{N \cdot \pi}}$.

- Törzsszám (N) (db/ha), a törzsek darabszáma, egy hektárra vetítve.

- Körlap $(G)\left(m^{2} / h a\right)$, a törzsek körlapjainak összege, egy hektárra vetítve.

- Fatérfogat $(\mathrm{V})\left(\mathrm{m}^{3} / \mathrm{ha}\right)$, a törzsek fatérfogatának összege, egy hektárra vetítve

- Az egészállomány törzsszám, körlap és fatérfogat szerinti elegyaránya (\%).

- Folyónövedék $\left(I_{f}\right)\left(\mathrm{m}^{3} / \mathrm{ha} / \mathrm{e} v\right)$ felvételi időszakonként számítható.

A jelenleg használt félig manuálisnak is nevezhető adatbázis megfelelő új fatermési táblák készítésére, azonban modern térinformatikai adatbázissá alakítása a jövő feladata, amivel a fatermési adatokat geodéziai-, termőhelyi- és klíma-adatbázisokkal is összevethetővé tehetjük (Király et al 2019). Ennek egyik lehetséges módja a tartamkísérleti adatbázis integrálása a SOE ERTI döntéstámogatási rendszerébe, a SiteViewer programba (Illés \& Fonyó 2017), ahol összevontan, erdőrészletenként megtalálhatóak topográfiai, termőhelyi, klíma illetve erdőtervi adatok is.

\section{AZ ELMÚLT HAT ÉVTIZED LEGFONTOSABB EREDMÉNYEI}

- A kísérleti bázis létrehozása (kísérleti területek országos hálózata)

- A kísérleti területek felét 1970 előtt, több mint kétharmadát pedig 1980 előtt hozták létre, ezért az idős korban kitűzött parcellák jelentős része már megszűnt.

- Az egyes fák fatérfogatának vizsgálata (fatömeg táblák)

- A fatömeg-számítási táblázatok első kiadását 1970-ben (Sopp 1970), második bővített kiadását 1974-ben adták ki (Sopp 1974). 2000-ben a harmadik kiadásban a táblákat függvényesítették, 
illetve 2013-ban megjelent egy változatlan negyedik kiadás is a szakmai igények kielégítésére (Sopp et al 2013).

- A faállományok fatermésének vizsgálata (fatermési táblák)

- $\mathrm{Az}$ országos fatermési táblákat fafajonként adták ki több szakaszban. Elsőként az első adatfelvételek eredményeiből készültek fatermési táblák az 1970-es évek elejére (Mendlik \& Birck 1968, Solymos 1968, Béky 1970, Kiss 1970, Solymos 1972, Solymos 1973, Hajdú 1974, Kovács 1974). Az elsőként elkészült fatermési táblákat, fontosságuk miatt, összesítve kiadták 1974-ben a fatömeg-számítási táblázatok egyik fejezeteként, kiegészítve egyéb fafajok tábláival (Sopp 1974). Második alkalommal a többszöri visszatérések eredményeivel pontosították a fatermési táblákat (Béky 1977, Béky 1981, Kovács 1981, Béky 1983, Kovács 1983, Mendlik 1983, Kovács 1985 , Kovács 1986, Kiss et al 1986, Solymos 1993, Kovács \& Veperdi 1993, Béky \& Somogyi 1995). Egyes fafajokból akár háromszor is készült megújított tábla. Adtak még ki helyi fatermési táblákat, melyek egy adott régióra vonatkoznak (Solymos 1966, Mendlik 1967, Faragó 1970, Kovács 1970). Szintén készültek sarj eredetü állományokra is külön táblák (Béky 1993). Különlegesség a grafikus fatermési tábla (Kiss 1972), vagy a statisztikai fatermési tábla (Kiss 1973) is, melyeket Kiss Rezső adott ki kocsányos tölgyesekre, azonban ezeket más fafajok kutatói végül nem vették át.

- Erdőnevelési irányelvek és erdőnevelési modellek kidolgozása (erdőnevelési modelltáblák)

- Az erdőnevelési modelltáblákat a fatermési táblák, illetve az erdőnevelési kutatások eredményeit felhasználva szerkesztették meg az 1980-as években (Kovács 1980, Mendlik 1986, Béky et al. 1986, Kovács \& Veperdi, 1993). Egyes modeltáblák a kutatók disszertációiban jelentek meg, beszerzésük nehézkes volt. Összefoglalva Solymos Rezső, „Erdőfelújitás és -nevelés a természetközeli erdőgazdálkodásban" című könyvének függelékében találhatóak meg (Solymos 2000).

- Az elmúlt évtizedek felvételi eredményeinek digitalizálása

- A kísérleti hálózat 6 évtizedes fennállása alatt keletkezett adatok digitális formára alakításával és feldolgozásával páratlan lehetőségek nyílnak a kutatás számra. A digitalizálás a személyi számítógépek elterjedésével indult meg az 1990-es években, azonban szisztematikusan 2012 óta zajlik.

\section{A tartamkísérleti hálózat eredményei a magyarországon megjelentetett legfontosabb szakirodalmak alapján}

A tartamkísérleti hálózat eredményeitaz ERTI kutatói folyamatosan publikálták, a 2000-es évekig elsősorban az ERTI saját kiadványában, az Erdészeti Kutatásokban, illetve az Erdészeti Lapok (illetve az Erdő) hasábjain, később egyéb kiadványokban is. A Solymos Rezső által vezetett kutatócsoport több száz publikációja, előadása is bizonyíték az általuk végzett munka sikerére. Az alábbiakban a tartamkísérletek eredményei alapján készült legfontosabb publikációkat gyüjtöttük ki fafajonkénti bontásban, időrendi sorrendben.

\section{Bükkösök}

Fekete Z. 1961: A bükk egységes magassági görbéinek gyakorlati használhatósága. Az Erdö, X. évf. 12. szám. 505-513. Márkus L. 1964: Állományszerkezeti vizsgálatok a különböző erdőtípusokba tartozó ugodi bükkösökben. Erdészeti kutatások, 60. évfolyam 1964. 1-3. szám. 33-47.

Mendlik G. 1967: Fatermési vizsgálatok a zalai bükkösökben. Erdészeti kutatások, 1967. 63. évfolyam 1-3. szám. 17-28. Mendlik G. 1967: A zalai bükkösök fatermési vizsgálata. Az Erdő, XVI. évfolyam 2. szám. 76-82.

Márkus, L., 1967. Faállomány minőségvizsgálatok bükköseinkben. Az Erdő, XVI. évfolyam 12. szám. 538-542.

Mendlik G. \& Birck O. 1968: Bükköseink fatermési vizsgálata. Erdészeti kutatások, 1968. 64. évfolyam 1-3. szám. 31-49. 
Mendlik G. 1974: A visegrádi bükk erdőnevelési sor 5. és 10. éves újrafelvételének eredményei. Erdészeti kutatások, 1973. Vol. 69. I. kötet. 183-190.

Mendlik G. 1976: A bükkösök erdönevelésének legújabb eredményei. Erdészeti kutatások, 1975. Vol 71. I. kötet. 159-165. Mendlik G. 1977: A bükkösök növekedésvizsgálatának új eredményei. Erdészeti kutatások, 1976. Vol 72. I. kötet. 27-32.

Mendlik G. 1978: A zalai bükkösök fatermési vizsgálatának újabb eredményei az újrafelvételek tükrében. Sopron: Doktori értekezés.

Mendlik G. 1979: Súlyos vadrágás rudaskorú bakonyi bükkösben. Az Erdő, XXVIII. évfolyam 10. szám. 458-460.

Mendlik G. 1981: Bükktörzsfa-, -vastagfa- és -összesfa-vizsgálatok új eredményei. Erdészeti kutatások, 1981. Vol. 74. 299-307.

Mendlik G. 1983: A bükkösök növedéke. Erdészeti kutatások, 1983. Vol. 75. 157-162.

Mendlik G. 1983: Bükk fatermési tábla (1983). Erdészeti kutatások, 1983. Vol. 75. 189-198.

Mendlik G. 1985: A bükkösök növedéke és záródása. Erdészeti kutatások, 1984-85. Vol. 76-77. 151-158.

Mendlik G. 1985: A törzsfanövedék és a záródás. Az Erdö, XXXIV. évfolyam 4. szám. 174-176.

Mendlik G. 1986: A gyertyános-bükkösök erdőnevelési modellje. Erdészeti kutatások, 1986. Vol. 78. 295-305.

Mendlik G. 1986: A hazai bükkösök fatermése, növedéke és erdőnevelése. Budapest: Kandidátusi értekezés.

Járó Z. 1990: A bükkösök szerves- és tápanyagforgalma. Erdészeti kutatások, 1988-89. Vol. 80-81. 83-98.

Mendlik G. 1990: A rácshálós erdőrészletszintű növedékvizsgálatok eredményei. Erdészeti kutatások, 1988-89. Vol. 80-81. 133-140.

Mátyás Cs., Borovics A. \& Führer E. 2005: Minőségi fatermesztés és a biodiverzitás. In: Solymos R. (ed): Erdő- és fagazdaságunk időszerű kérdései. Budapest: MTAAgrártudományok Osztálya Erdészeti Bizottsága, 83-94.

Kollár T. 2019: Új adatok a magyarországi bükkösök faterméséről. In: Facskó F., Király G. (ed): Soproni Egyerem Erdőmérnöki Kar VII. Kari Tudományos Konferencia - a konferencia elöadásainak és posztereinek kivonatai, Sopron, Soproni Egyetem Kiadó, 19.

Kollár T. 2019: Új adatok a magyarországi bükkösök faterméséről. In: Facskó F., Király G. (ed): Soproni Egyetem Erdőmérnöki Kar VII. Kari Tudományos Konferencia - Konferencia kiadvány, Sopron, Soproni Egyetem Kiadó, 76-81.

\section{Cseresek}

Hajdú G. 1974: Fatermési vizsgálatok csertölgy-állományokban. Erdészeti kutatások, 1974. Vol. 69. I. kötet. 171-182.

Kovács F. 1983: Csertölgyállományok törzsszámának és fatérfogatának megoszlása átmérőfokonként. Erdészeti kutatások, 1983. Vol. 75. 209-223.

Kovács F. 1983: A csertölgyállományok fatermése. Erdészeti kutatások, 1983. Volt. 75. 179-188.

Béky A., Hajdú G. \& Kovács F. 1986: A cseres-tölgyesek nevelése. Erdészeti kutatások, 1986. Vol. 78. 283-293.

Kovács F. 1988: A cseresek növedéke. Erdészeti kutatások, 1987. Vol. 79. 71-77.

Béky A. 1997: Gyérítési technológiák hatása a faállomány szerkezetre és a növedékre. Erdészeti kutatások, Vol 86-87. 73-88.

\section{Kocsánytalan tölgyesek}

Solymos R. 1965: Gyérítési vizsgálatok a lajosforrási kocsánytalan tölgyesekben. Erdészeti kutatások, 1965. 61. évfolyam 1-3. szám. 29-38.

Béky A. 1981: Mag eredetü kocsánytalantölgyesek fatermése. Erdészeti kutatások, 1981. Vol. 74. 309-320.

Béky A. 1983: A nevelövágások hatása a faegyedek vastagsági növekedésére kocsánytalan tölgyesekben. Erdészeti kutatások, 1983. Vol. 75. 173-177.

Béky A. 1984: A kocsánytalan tölgyesek egészségi állapota az erdőnevelési és fatermési kísérleti területeken. Az Erdő, XXXIII. évfolyam 8. szám. 351-352.

Solymos R. 1984: Elegyes kocsánytalan tölgyesek és bükkösök faállomány-szerkezete és nevelése. Sopron: Doktori értekezés. 
Igmándy Z., Béky A., Pagony H., Szontágh P., Varga F. 1986: A kocsánytalan tölgypusztulás helyzete hazánkban 1985-ben. Az Erdő, XXXV. évfolyam 6. szám. 255-259.

Béky A. 1986: Tölgy magtermelő állományok nevelése. Az Erdő, XXXV. évfolyam 3. szám. 93-96.

Béky A. 1988: A tölgyhervadás-folyamat vizsgálatának tapasztalatai a hosszú lejáratú kocsánytalan tölgy fatermési kísérleti területeken. Erdészeti kutatások, 1987. Vol. 79. 241-242.

Béky A. 1990: A kocsánytalan tölgy pusztulása a hosszú lejáratú erdönevelési és fatermési kísérleti területeken. Erdészeti kutatások, 1988-89. Vol. 80-81. 281-283.

Béky A. 1993: Sarj kocsánytalan tölgyek fatermése. Erdészeti kutatások, 1990-91. Vol. 82-83./ll. 181-197.

Béky A. \& Solymos R. 1993: Egy kocsánytalan tölgy erdőnevelési sor tanulságai. Erdészeti kutatások, 1990-91. Vol. 82-83. 227-235.

Béky A. 1995: A nevelővágások hatása a növedékképződésre kocsánytalan tölgy állományokban. Erdészeti kutatások, 1995. Vol. 85. 125-131.

Solymos R. \& Béky A. 1995: Elegyes erdők szerkezetének és fatermésének kutatása: egy 25 éven keresztül folytatott 32 parcellás kísérlet eredményei. Erdészeti kutatások, 1995. Vol. 85. 91-111.

Béky A. \& Somogyi Z. 1995: Fatermési tábla optimális szerkezetü gyertyános-kocsánytalan tölgyesre. Erdészeti kutatások, 1995. Vol. 85. 49-78.

Szabados I. 1997: Az évgyürüelemzés felhasználása növedékveszteség megállapítására, és a módszer további alkalmazási lehetőségei. Erdészeti kutatások, 1997. Vol. 86-87. 89-99.

Béky A. \& Somogyi Z. 1999: Gyertyános-kocsánytalan tölgyesek fatermése az elegyesség függvényében. Erdészeti kutatások, 1999. Vol. 89. 61-72.

Szabados I. 2004: A kocsánytalan tölgy évgyürüszélessége és a különféle csapadékösszegek kapcsolata. Erdészeti kutatások, 2002-2004. Vol. 91. 19-25.

Szabados I. 2004: Néhány dendrokronológiában alkalmazott eljárás hazai felhasználása kocsánytalan tölgyeken. Erdészeti kutatások, 2002-2004. Vol. 91. 227-234.

\section{Kocsányos tölgyesek}

Kiss R. 1965: Fatermési vizsgálatok kocsányos tölgy állományokban. Sopron: Doktori értekezés.

Kiss R. 1966: Fatermési vizsgálatok kocsányos tölgyesekben. Erdészeti kutatások, 1966. 62. évfolyam 1-3. szám. 27-33.

Kiss R. 1970: Kocsányos tölgyeseink fatermése. Az Erdő, XIX. évfolyam 2. szám. 74-77.

Kiss R. 1971: Fatermési tábla a magyarországi kocsányos tölgyesekre. Erdészeti kutatások, 1970. 66. évfolyam. 103-114.

Kiss R. 1972: Grafikus, normatív jellegű fatermési tábla kocsányos tölgyesekre. Erdészeti kutatások, 1971. Vol. 67. I. kötet. 243-259.

Kiss R. 1973: Statisztikai fatermési tábla kocsányos tölgyesekre. Erdészeti kutatások, 1972. Vol. 68. I. kötet. 175-194.

Kiss R. 1976: A tiszántúli kocsányos tölgyesekben folytatott fatermési és állománynevelési kutatások tanulságaiból. Erdészeti kutatások, 1975. Vol. 71. I. kötet. 36-39.

Király L. \& Gémesi J. 1976: A Backman-függvény alkalmazása Kiss Rezső kocsányos tölgy fatermési táblájára. Az Erdő, XXV. évfolyam 5. szám. 201-207.

Kiss R. 1980: Kocsányostölgyeseink növedéke. Erdészeti kutatások, 1980. Vol. 73. I. kötet. 165-168.

Somogyi Z. 1985: A kocsányostölgy hosszú lejáratú kísérleti területek felvételeinek számítógépes adattárolása és adatfeldolgozása. Erdészeti kutatások, 1984-85. Vol. 76-77. 213-219.

Juhász G. 1986: Kocsányostölgy-állományokban végzett fatermési, állományszerkezeti és erdőnevelési kutatások. Erdészeti kutatások, 1986. Vol. 78. 311-312.

Kiss R., Somogyi Z. \& Juhász G. 1986: Kocsányos tölgyfatermési tábla (1985). Erdészeti kutatások, 1986. Vol. 78. 265-282.

Borovics A., Cseke K. \& Molnár T. 2012: Genetic consequences of utilization artificial populations in forestry. Isparta-Turkey, Seed Orchards an Breeding Theory IUFRO Conference - Proceedings, 67-71. 


\section{Gyertyánosok}

Béky A. 1970: Gyertyánosaink fatermése. Erdészeti kutatások, 1969. (65. évfolyam) 2-3. szám. 51-65.

Béky A. 1970: A gyertyán helye erdőművelésünkben. Az Erdő, XIX. évfolyam 2. szám. 82-88.

Béky A. 1971: Gyertyánosok nevelésének főbb kérdései. Erdészeti kutatások, 1970. (66. évfolyam). 87-96.

Béky A. 1972: Gyertyánosok törzsszámának és fatömegének megoszlása átmérö-méretcsoportonként. Erdészeti kutatások, 1971. Vol. 67. I. kötet. 261-275.

Béky A. 1977: Új gyertyánfatermési tábla. Erdészeti kutatások, 1976. Vol. 72. I. kötet. 33-47.

Béky A. 1983: Országos fatermési tábla gyertyánállományokra. Erdészeti kutatások, 1983. Vol. 75. 199-207.

Béky A. 1986: Fő fafajaink és az azokhoz társuló gyertyán fatermési összehasonlító vizsgálatok eredményei. Erdészeti kutatások, 1986. Vol. 78. 219-224.

Béky A. 2001: A gyertyánosok neveléséről. Erdészeti kutatások, 2000-2001. Vol. 90. 67-86.

\section{Körisek}

Kovács F. 1974: A kőris fatermése. Erdészeti kutatások, 1973. Vol 69. I. kötet. 217-222.

Kovács F. 1980: A kőrisállományok erdőnevelési modellje. Az Erdő, XXIX. évfolyam 3. szám. 129-133.

Kovács F. 1981: Új kőrisfatermési táblák. Erdészeti kutatások, 1981. Vol. 74. 321-334.

Kovács F. 1981: A hazai Fraxinaster csoportba tartozó kőrisek fatermése és nevelése. Sopron: Doktori értekezés.

Kovács F. 1986: A mag eredetű kőrisek fatermése. Erdészeti kutatások, 1986. Vol. 78. 225-240.

Kovács F. 1986: A magaskőris-állományok törzsszám- és fatérfogat-megoszlása az átmérőfokok függvényében. Erdészeti kutatások, 1986. Vol. 78. 247-259.

\section{Erdei fenyvesek}

Solymos R. 1963: Erdőnevelési és fatermési vizsgálatok Nyugat-dunántúli erdeifenyvesekben. Erdészeti kutatások, 59. évfolyam 1-2. szám. 133-162.

Solymos R. 1963: A fák koronaméreteinek helyes kialakitása erdőnevelési feladat. Az Erdő, XII. évfolyam 10. szám. 474480.

Solymos R. 1963: Az erdeifenyő növekedésmenetének erdőnevelési vonatkozásai. Az Erdő, XII. évfolyam 5. szám. kötet, pp. 217-224.

Solymos R. 1965: Erdeifenyveseink ápolása és nevelése az erdőnevelési és fatermési kutatások legújabb eredményeinek tükrében. Az Erdő, XIV. évfolyam 3. szám. 113-120.

Solymos R. 1965: Fatermési táblák hegy- és dombvidéki erdeifenyveseinkre. Az Erdő, XIV. évfolyam 8. szám. 337-347.

Solymos R. 1965: Nyugat-dunántúli erdeifenyveseink fatermése. Budapest: Kandidátusi értekezés.

Solymos R. 1966: Állományszerkezeti és fatermési vizsgálatok Nyugat-dunántúli erdeifenyvesekben. Erdészeti kutatások, 62. évfolyam 1-3. szám. 47-66.

Solymos R. 1966: Irányelvek az erdeifenyvesek gazdaságos tisztitására. Az Erdő, XV. évfolyam 6. szám. 244-250.

Solymos R. 1967: Az állományápolási és tisztítási munkák racionalizálása erdeifenyvesekben. Erdészeti kutatások, 1967. 63. évfolyam 1-3. szám. 29-49.

Solymos R. 1972: Az erdeifenyő-állományok fatermése Magyarországon. Erdészeti kutatások, 1971. Vol. 67. I. kötet. 203232.

Solymos R. 1974: Az erdeifenyő-állományok fakészletének megoszlása mellmagassági átmérőosztályok szerint. Erdészeti kutatások, 1974. Vol. 70. I. kötet. 157-171.

Adorján J. 1976: Nyugat-dunántúli erdeifenyvesek termöhelyi értékelése. Erdészeti kutatások, 1975. Vol. 71. I. kötet. 339346.

Solymos R. 1976: A nyírségi erdei fenyőállományok nevelésének fontosabb irányelvei. Erdészeti kutatások, 1975. Vol. 71. I. kötet. 34-36. 
Solymos R. 1978: Növedékkutatási eredmények hazai erdeifenyvesekben. Az Erdő, XXVII. évfolyam 6. szám. 252-256.

Solymos R. 1983: Homoki erdeifenyvesek törzsszáma és fatermése. Az Erdő, XXXII. évfolyam 1. szám. 33-38.

Solymos R. 1983: Az erdeifenyő erdősitések ültetési hálózata. Az Erdő, XXXII. évfolyam 4. szám. 147-150.

Solymos R. 1993: Új fatermési táblák erdeifenyőre. Erdészeti kutatások, 1990-91. Vol. 82-83./II. 357-382.

Veperdi G. 1997: Hótörés és gyérülés vizsgálata 27 éves nyírségi homoki erdeifenyő kísérleti területen. Erdészeti kutatások, 1997. Vol. 86-87. 101-113.

\section{Fekete fenyvesek}

Kovács F. 1967: A bakonyi feketefenyvesek fatermésének vizsgálata. Erdészeti kutatások, 1967. 63. évfolyam 1-3. szám. 7-15.

Faragó S. 1970: A feketefenyvesek fatermése a nagyalföldön. Erdészeti kutatások, 1969. (65. évfolyam) 2-3. szám. 25-39.

Kovács F. 1970: Helyi fatermési tábla a dunántúli feketefenyvesekre. Erdészeti kutatások, 1969. (65. évfolyam) 2-3. szám. 41-44.

Faragó S. 1971: Néhány összefüggés az alföldi feketefenyvesek főbb állományszerkezeti tényezői között. Erdészeti kutatások, 1970. (68. évfolyam). 97-102.

Kovács F. 1973: Növekedési vizsgálatok a bakonyi feketefenyő-kísérleti területeken. Erdészeti kutatások, 1972. Vol. 69. I. kötet. 145-153.

Solymos R. 1973: A feketefenyő fatermése és állományszerkezeti viszonyai Magyarországon. Erdészeti kutatások, 1972. Vol. 68. I. kötet. 155-174.

Nguyen D. C. 1981: Fatermési vizsgálatok délalföldi feketefenyvesekben. Az Erdő, XXX. évfolyam 8. szám. 338-341.

Nguyen D. C. 1981: Összefüggések a feketefenyő koronaméretei és növekedése között. Az Erdő, XXX. évfolyam 7. szám. 309-313.

Kovács F. 1985: A feketefenyő-állományok törzsszámának és fatérfogatának megoszlása átmérőfokonként. Erdészeti kutatások, 1984-85 Vol. 76-77. 159-173.

Kovács F. 1985: A feketefenyő fatermése. Erdészeti kutatások, 1984-85 Vol 76-77. 175-190.

Veperdi G. 1990: Feketefenyő-ültetési hálózati kísérlet dél-alföldi homoktermőhelyen. Erdészeti kutatások, 1988-89. Vol. 80-81. 123-132.

Kovács F. \& Veperdi G. 1993: A feketefenyő fatermése és erdőnevelési modellje. Erdészeti kutatások, 1990-91. Vol. 82-83./ II. 328-344.

Veperdi G. 1993: Arid homoktermőhelyek Pinus Nigra Arn. fafajjal történő hasznositása Magyarországon. Erdészeti kutatások, 1990-91. Vol. 82-83./II. 391-397.

\section{Lucfenyvesek}

Solymos R. 1964: A lucfenyőtermesztés szerepe papírfaellátásunk megjavitásában. Az Erdő, XIII. évfolyam 9. szám. 418422.

Solymos R. 1968: Új fatermési táblák a magyarországi lucfenyvesekre. Erdészeti kutatások, 1968. 64. évfolyam 1-3. szám. 7-30.

Solymos R. 1968: A lucfenyő fatermése és termesztésének lehetőségei Magyarországon. Az Erdő, XVII. évfolyam 3. szám. 109-116.

Solymos R. 1970: A lucfenyő-állományok korszerű nevelésének főbb kérdései. Erdészeti kutatások, 1969. (65. évfolyam) 2-3. szám. 7-24.

Solymos R. 1974: A lucfenyő-állományok szerkezetének és fatermésének vizsgálata. Erdészeti kutatások, 1973. Vol. 69. I. kötet. 125-143.

Veperdi G. \& Veperdi I. 2004: Lucfenyő ültetési hálózati és erdőnevelési kísérleti terület (Pölöske 17c2, d2) aktuális újrafelvételezésének eredményei. Erdészeti kutatások, 2002-2004. Vol. 91. 77-93. 


\section{Fenyő fafajokkal együttesen foglalkozó cikkek}

Solymos R. 1968: Adatok és javaslatok a fenyőállományok nevelésének racionalizálásához. Az Erdő, XVII. évfolyam 12. szám. 535-540.

Solymos R. 1969: Adatok a nagycsemetés erdőfelújitáshoz. Az Erdő, XVIII. évfolyam 6. szám. 250-252.

Solymos R. 1972: Az erdeifenyő, a feketefenyő és a lucfenyő állományok fatermése és nevelésük irányelvei Magyarországon. Budapest: Akadémiai doktori értekezés.

Solymos R. 1974: A nevelővágások technológiájának fejlesztése, különös tekintettel a gépesitésre. Erdészeti kutatások, 1973. Vol. 69. I. kötet. 145-153.

Solymos R. 1975: Az iparilag hasznositható szervesanyag vizsgálatának újabb eredményei erdei- és feketefenyő állományokban. Az Erdő, XXIV. éfvolyam 9. szám. 411-415.

Solymos R. 1976: Hosszúlejáratú erdőnevelési kísérletek a veszprémkörnyéki fenyvesekben. Az Erdő, XXV. évfolyam 7. szám. 320-325.

Solymos R. 1977: A fenyőállományok nevelésének egyszerüsitése. Az Erdő, XXVl. évfolyam 8. szám. 344-346.

Harkai L. 1981: A zalaerdődi fenyőhálózati kísérletek értékelése. Erdészeti kutatások, 1981. Vol. 74. 89-96.

Solymos R. 1982: Fenyőtermesztésünk időszerű kérdései. Az Erdő, XXXI. évfolyam 8. szám. 333-342.

Horváth I. 1985: Fenyő koronavizsgálatok erdőnevelési vonatkozásai. Az Erdő, XXXIV. évfolyam 7. szám. 307-311.

Veperdi G. 1990: Az erdei- és feketefenyö-ültetési hálózati kísérletek újabb eredményei. Erdészeti kutatások, 1988-89. Vol.

80-81. 289-292.

Veperdi G. \& Veperdi I. 1998: A felsőmagasság változásának vizsgálata fenyő ültetési hálózati kísérletekben. Erdészeti kutatások, 1998. Vol. 88. 207-220.

Veperdi G. 1998: Peresznye állabok erdölése. Erdészeti kutatások, 1998. Vol. 88. 45-52.

Módszertani, összefoglaló és egyéb jellegü publikációk

Kaán K. 1905: Erdőgyérités. Erdészeti Lapok, 1905. augusztus hó. VIII. füzet. XLIV évfolyam. 623-680.

Sopp L. 1955: A kísérleti állományápolások módszere és gyakorlati tanulságai. Erdészeti kutatások, 1955. 2. szám. 121154.

Majer A. 1957: Az erdőnevelési kutatás fejlesztéséről. Az Erdő, Vl évf. 11. szám. 422-426.

Birck O., Kiss R, Márkus L., Solymos R., Tallós P. 1962: A hosszúlejáratú erdőnevelési és fatermési kísérleti területek kitüzésének, felvételezésének és fenntartásának irányelvei. Erdészeti kutatások, 58. évfolyam 1-3. szám. 217-259.

Solymos R. 1962: Erdőnevelési és faterméstani kutatások az ERTI-ben. Az Erdő, XI. évfolyam 12. szám. 560-565.

Jérőme R. 1963: Erdőnevelési, faterméstani bemutató és előadássorozat az Erdészeti Tudományos Intézetben. Az erdő, XII. évfolyam 11. szám. 503-508.

Kiss R. 1964: Új rendszerü, kör alakú kísérleti területek létesítésének, felvételének és feldolgozásának módszere. Az erdő, (99.) XIII. évfolyam 8. szám. 366-373.

Márkus L. 1965: A faterméstani és az állományszerkezeti vizsgálatok során alkalmazott feldolgozási és értékelési eljárások. Erdészeti kutatások, 61. évfolyam 1-3. szám. 7-28.

Kiss R. 1965: Álló fák koronaméretének és állományok gyérítettségi fokának meghatározása új viszonyszámok segítségével. Az Erdő, XIV. évfolyam 3. szám. 126-132.

Solymos R. 1969: Az optimális törzsszámtartás szerepe az erdőnevelés racionalizálásában. Az Erdő, XVIII. évfolyam 5. szám. 204-208.

Solymos R. 1969: Új hazai fatermési táblák. Az Erdő, XVIII. évfolyam 3. szám. 125-129.

Sopp L. 1970: Fatömegszámítási táblázatok. Budapest, Mezőgazdasági kiadó.

Solymos R. 1970: A kutatási eredmények alkalmazása az erdőnevelés fejlesztési irányelveinek kidolgozásában. Az Erdő, XIX. évfolyam 6. szám. 274-278.

Solymos R. 1971: Erdőnevelési és faterméstani kutatásaink eredményei. Erdészeti kutatások, 1970. (66. évfolyam). 19-23. 
Solymos R. 1971: Kutatási eredmények hasznositása az erdőnevelés fejlesztésében. Erdészeti kutatások, 1970. (66. évfolyam). 69-86.

Solymos R. 1974: Erdőnevelésünk fejlesztésének irányelvei és lehetőségei. Az Erdő, XII. évfolyam 8. szám. 361-365.

Sopp L., Adorján J., Béky A., Birck O., Faragó S., Fogarasi D., Harkay L., Kiss R., Kovács F., Márkus L., Mendlik G., Palotás

F., Solymos R., Szodfridt I., Tuskó L. 1974: Fatömegszámítási táblázatok fatermési táblákkal, második, átdolgozott, bővitett kiadás. Budapest: Mezőgazda Kiadó.

Gál J. 1978: A Backman-függvény alkalmazása hazai fatermési tábláinkra. Az Erdő, XXVII. évfolyam 12. szám. 564-567.

Solymos R. 1980: Erdőnevelési kutatások a fatermelési rendszerek kialakitása érdekében. Erdészeti kutatások, 1980. Vol. 73. I. kötet. 149-156.

Solymos R. 1980: Az erdőnevelés helyzete és fejlesztése - gépek a „V” fák között. Az Erdő, XXIX. évfolyam 3. szám. kötet, pp. $117-120$

Solymos R. 1982: Fatermesztési modellek szerepe a távlati fejlesztésben. Az Erdő, XXXI. évfolyam 5. szám. 220-222.

Solymos R. 1984: Az erdőnevelési kutatás Magyarországon. Az Erdő, XXXIII. évfolyam 2. szám. 57-64.

Keresztesi B. 1986: Az erdészetfejlesztés és az erdészeti kutatás helyzete és problémái. Erdészeti kutatások, 1986.Vol. 78. 5-12.

Somogyi Z. 1986: Mikroszámítógép alkalmazása a faterméstani vizsgálatokban. Erdészeti kutatások, 1986. Vol. 78. 261264.

Sali E. 1986: A fatermési táblák megbízhatóságáról. Az Erdő, XXXV. évfolyam 3. szám. 134-138.

Somogyi Z. 1987: Mikroszámítógép alkalmazása a terepi adatgyüjtésben. Az Erdő, XXXVI. évfolyam 6. szám. 277-279.

Somogyi Z. 1987: A növedékmeghatározás néhány elméleti és gyakorlati kérdése. Budapest: Kandidátusi értekezés.

Bondor A. 1988: 25 éves a magyar szervezett, hosszú lejáratú fatermési kutatás. Az erdö, XXXVII. évfolyam 10. szám. 446-453.

Halupa L. 1988: Az erdőművelési és fatermési kutatásról. Az Erdő, XXXVII. évfolyam 10. szám. 441-445.

Solymos R. 1989: Az erdőgazdálkodás fejlesztése és az erdészeti kutatás. Az Erdő, XXXVIII. évfolyam 7. szám. 290-294.

Somogyi Z. 1989: A változatosság, mint a természet egyik legfontosabb jelensége: gondolatok a fatermési táblák és függvények alkalmazásához. Az erdő, XXXVIII. évfolyam 5. szám. 214-218.

Béky A., Bondor A., Gabnai E., Hajdú G., Halupa L., Kiss R., Mendlik G., Rédei K., Solymos R., Veperdi G. 1993: A hosszúlejáratú erdőnevelési és fatermési kísérletek létesitésének, felvételének és fenntartásának továbbfejlesztett irányelvei. Erdészeti Kutatások, 1990-91. Vol. 82-83./I. 197-213.

Somogyi Z. 1994: Faállományok gyérülése a fatermési osztály függvényében. Erdészeti kutatások, 1994. Vol. 84. 67-79.

Veperdi G. 1995: Állományfelvételi adatok feldolgozása, feldolgozó algoritmusok Exel 5.0 táblázatkezelő programra, kezelés útmutató. Budapest: Erdészeti Tudományos Intézet, Erdőművelési és Fatermési osztály.

Solymos R. 1998: Az erdészeti fatermési és erdőnevelési kutatások eredményei és alkalmazásuk az erdőgazdasági gyakorlatban (1958-1998). Erdészeti kutatások, Vol. 88. 13-36.

Somogyi Z. 1998: Van-e szükség fatermési és erdőnevelési kutatásokra? Erdészeti kutatások, Vol. 88. 37-44.

Somogyi Z. 1998: Az erdőművelési és fatermési kutatásokról az erdészeti kutatások centenáriuma kapcsán. Erdészeti Lapok, CXXXIII. évfolyam 10. szám. 305-308.

Solymos R. 2000: Erdőfelújitás és -nevelés a természetközeli erdőgazdálkodásban. Budapest: Mezőgazdasági Szaktudás Kiadó.

Solymos R. 2004: A tudomány és a kutató, a kutatás és a kutatási metodika. Erdészeti kutatások, 2002-2004. Vol. 91. 215-226.

Solymos R. 2008: Erdészettudomány és erdőgazdálkodás I.. Erdészeti kutatások, 2007-2008. Vol. 92. 9-26.

Solymos R. 2009: Erdészeti produkcióbiológiai kutatások - avagy rekviem a tartamkísérletekért. Magyar tudomány, 946953.

Solymos R., Béky A., Rédei K., Szabados I., Veperdi G. 2013: Erdőnevelési, faállomány-szerkezeti és fatermési kutatások eredményei és a hosszúlejáratú kísérletek fél évszázada. In: Faragó S. (ed), szerk. Monitoring az erdészetben és vad- 
gazdálkodásban - A Magyar Tudományos Akadémián 2012. november 21-én megtartott tudományos ülés előadásai. Sopron: Nyugat-magyarországi Egyetem, 21-28.

Solymos R. 2013: Hosszú lejáratú kísérletek az erdészettudományi kutatások területén I.. Erdészeti Lapok, CXLVIII. évfolyam 2. szám. 37-39.

Solymos R. 2013: Hosszú lejáratú kísérletek az erdészettudományi kutatások területén II.. Erdészeti Lapok, CXLVII. évfolyam 3. szám. 72-73.

Sopp L., Adorján J., Béky A., Birck O., Dérföldi A., Fadgyas K., Faragó S., Fekete Z., Gabnai E., Halupa L., Király L., Kiss R.,

Kovács F., Márkus L., Mendlik G., Palotás F., Somogyi Z., Solymos R., Szodfridt I., Tuskó L. 2013: Fatömeg számítási táblázatok. negyedik, változatlan kiadás, Budapest: Nemzeti Élelmiszerlánc-biztonsági Hivatal Erdészeti Igazgatóság. Illés G., Kollár T., Veperdi G. \& Führer E. 2014: A zalai faállományok magassági növekedésének és fatermésének kapcsolata a termőhelyi tényezőkkel. Erdészettudományi Közlemények, 4. évfolyam 2. szám. 77-89.

Illés G. \& Fonyó T. 2017: Új digitális termőhelytérkép-alkalmazás. Erdészeti Lapok, Március, CLI. évf. 3. szám. 75-78.

Kollár T., Veperdi G. \& Rédei K. 2018: A NAIK Erdészeti Tudományos Intézet hosszúlejáratú fatermési, erdőnevelési és hálózati tartamkísérleteinek múltja, jelene és jövője. Erdészeti Lapok, október, CLIII. évfolyam 2018. október. 306-310. Kollár T. 2019: The long-term forest yield, silvicultural and planting experiment network of the NARIC-FRI. In: Makádi M. (ed): 2nd Conference on long-term field experiments "LOTEX 2019” on the 90th anniversary of Westsik's experiment. Nyíregyháza, University of Debrecen, 60-64.

Király, G., Brolly, G. \& Kollár, T., 2019. A NAIK-ERTI hosszútávú kísérleteinek geomatikai szempontú javítása és értékelése a Soproni-hegységben. In: Facskó F., Király G. (ed): Soproni Egyerem Erdőmérnöki Kar VII. Kari Tudományos Konferencia - a konferencia előadásainak és posztereinek kivonatai, Sopron, Soproni Egyetem Kiadó, 18.

\section{A KUTATÁSOK TOVÁBBI FELADATAI}

- A kísérleti hálózat fenntartása és szükség szerinti bővítése.

- A kísérletek fenntartásakor nem volt kapacitás új parcellák kitűzésére, így a hálózat folyamatosan elöregszik, a kísérleti parcellák száma pedig a végvágásokkal csökken.

- A fatermési táblák folyamatos továbbfejlesztése, új fatermési táblák készítése

- A táblákat az új eredményekkel, korszerű feldolgozással és többlet adatokkal javasolt megújítani.

A becslésre használt táblákat és függvényeket folyamatosan ellenőrizni, illetve változtatni kell a hosszú lejáratú kísérleti területek újrafelvételeivel (Somogyi 1989).

- A termőhely és a fatermés közötti kapcsolatok részletes feltárása, ezen belül a klímaváltozás múltbéli hatásainak vizsgálata, illetve jövőbeli hatásainak becslése.

- Elegyes állományok és örökerdő üzemmódban kezelt többkorú, változatos szerkezetű állományokra is alkalmazható fatermési és erdőnevelési modellek kialakítása.

- A nevelővágások hatásának vizsgálata a fatermési vonatkozások mellett a genetikai változatosságra.

- Precíziós erdőgazdálkodás támogatása.

- Ökoszisztéma szolgáltatások és az erdőművelési módok kapcsolatának vizsgálata.

- Referencia területekként való felhasználás távérzékelési kutatások számára.

- Az eredmények publikálása, gyakorlati bevezetése.

Irányelvünk, hogy a hosszúlejáratú kísérleti területek lehetőség szerint alkalmasak legyenek komplex kutatásokra, ami az egyes kísérleti eredmények többirányú értékelését teszi lehetővé (erdőnevelési, fatermési, erdőtipológiai, termőhelyfeltárási, genetikai, ökológiai, távérzékelési stb. vizsgálatok). A kísérleti területek nyitottak az azokat felhasználni szándékozó kutatók számára, az együttműködéseket az Erdészeti Tudományos Intézet támogatja. 


\section{KÖSZÖNETNYILVÁNÍTÁS}

Köszönettel tartozunk a hivatkozásokban és irodalomjegyzékben megjelölt kutatókon felül minden olyan ERTI dolgozónak, akik munkája nélkül ez a hálózat nem müködhetett és működhet ma sem. Kiemelnénk Kocsisné Antal Judit munkáját, aki a digitalizálás legnagyobb részét végezte az elmúlt két évtizedben. Köszönet illeti a magyarországi erdőgazdaságokat is, hogy évtizedekig helyet adtak és adnak ma is a kutatási területeknek. Ajánljuk a cikket Solymos Rezső (1929-2019) emlékének. Köszönettel tartozunk Illés Gábornak, Kottek Péternek és Gál Jánosnak a kézirathoz füzött javaslataikért.

\section{FELHASZNÁLT IRODALOM}

Béky A. \& Somogyi Z. 1995: Fatermési tábla optimális szerkezetű gyertyános-kocsánytalan tölgyesre. Erdészeti kutatások 85: 49-78.

Béky A. 1970: Gyertyánosaink fatermése. Erdészeti kutatások 65(2-3): 51-65.

Béky A. 1977: Új gyertyánfatermési tábla. Erdészeti kutatások 72(1): 33-47.

Béky A. 1981: Mag eredetű kocsánytalantölgyesek fatermése. Erdészeti kutatások 74: 309-320.

Béky A. 1983: Országos fatermési tábla gyertyánállományokra. Erdészeti kutatások 75: 199-207.

Béky A. 1993: Sarj kocsánytalan tölgyek fatermése. Erdészeti kutatások 82-83(2): 181-197.

Béky A., Bondor A., Gabnai E., Hajdú G., Halupa L., Kiss R., Mendlik G., Rédei K., Solymos R., Veperdi G. 1993: A hosszúlejáratú erdőnevelési és fatermési kísérletek létesitésének, felvételének és fenntartásának továbbfejlesztett irányelvei. Erdészeti kutatások 82-83(2): 197-213.

Béky A., Hajdú G. \& Kovács F. 1986: A cseres-tölgyesek nevelése. Erdészeti kutatások 78: 283-293.

Birck O., Kiss R, Márkus L., Solymos R., Tallós P. 1962: A hosszúlejáratú erdőnevelési és fatermési kísérleti területek kitüzésének, felvételezésének és fenntartásának irányelvei. Erdészeti kutatások 58(1-3): 217-259.

Faragó S. 1970: A feketefenyvesek fatermése a nagyalföldön. Erdészeti kutatások 65(2-3): 25-39.

Hajdú G. 1974: Fatermési vizsgálatok csertölgy-állományokban. Erdészeti kutatások 69(1): 171-182.

Illés G. \& Fonyó T. 2017: Új digitális termőhelytérkép-alkalmazás. Erdészeti Lapok 151(3): 75-78.

Jérőme R. 1963: Erdőnevelési, faterméstani bemutató és előadássorozat az Erdészeti Tudományos Intézetben. Az erdő 12(11): 503-508.

Kaán K. 1905: Erdőgyérítés. Erdészeti Lapok 44(8): 623-680.

Király, G., Brolly, G. \& Kollár, T., 2019. A NAIK-ERTI hosszútávú kísérleteinek geomatikai szempontú javítása és értékelése a Soproni-hegységben. In: Facskó F., Király G. (eds): Soproni Egyerem Erdőmérnöki Kar VII. Kari Tudományos Konferencia - a konferencia előadásainak és posztereinek kivonatai, Sopron, Soproni Egyetem Kiadó, 18.

Kiss R. 1970: Kocsányos tölgyeseink fatermése. Az Erdő 19(2): 74-77.

Kiss R. 1972: Grafikus, normatív jellegü fatermési tábla kocsányos tölgyesekre. Erdészeti kutatások 67(1): 243-259.

Kiss R. 1973: Statisztikai fatermési tábla kocsányos tölgyesekre. Erdészeti kutatások 68(1): 175-194.

Kiss R., Somogyi Z. \& Juhász G. 1986: Kocsányos tölgyfatermési tábla (1985). Erdészeti kutatások 78: 265-282.

Kollár T., Veperdi G. \& Rédei K. 2018: A NAIK Erdészeti Tudományos Intézet hosszúlejáratú fatermési, erdőnevelési és hálózati tartamkísérleteinek múltja, jelene és jövője. Erdészeti Lapok 153(10): 306-310.

Kovács F. \& Veperdi G. 1993: A feketefenyő fatermése és erdőnevelési modellje. Erdészeti kutatások 82-83(2): 328-344.

Kovács F. \& Veperdi G. 1993: A feketefenyő fatermése és erdőnevelési modellje. Erdészeti kutatások 82-83(2): 328-344.

Kovács F. 1970: Helyi fatermési tábla a dunántúli feketefenyvesekre. Erdészeti kutatások 65(2-3): 41-44.

Kovács F. 1974: A kőris fatermése. Erdészeti kutatások 69(1): 217-222.

Kovács F. 1980: A kőrisállományok erdőnevelési modellje. Az Erdő 29(3): 129-133. 
Kovács F. 1981: Új kőrisfatermési táblák. Erdészeti kutatások 74: 321-334.

Kovács F. 1983: A csertölgyállományok fatermése. Erdészeti kutatások 75: 179-188.

Kovács F. 1985: A feketefenyő fatermése. Erdészeti kutatások 76-77: 175-190.

Kovács F. 1986: A mag eredetű kőrisek fatermése. Erdészeti kutatások 78: 225-240.

Majer A. 1957: Az erdőnevelési kutatás fejlesztéséről. Az Erdő 6(11): 422-426.

Márkus L. 1965: A faterméstani és az állományszerkezeti vizsgálatok során alkalmazott feldolgozási és értékelési eljárások. Erdészeti kutatások 61(1-3): 7-28.

Mendlik G. \& Birck O. 1968: Bükköseink fatermési vizsgálata. Erdészeti kutatások 64(1-3): 31-49.

Mendlik G. 1967: A zalai bükkösök fatermési vizsgálata. Az Erdő 14(2): 76-82.

Mendlik G. 1983: Bükk fatermési tábla (1983). Erdészeti kutatások 75: 189-198.

Mendlik G. 1986: A gyertyános-bükkösök erdőnevelési modellje. Erdészeti kutatások 78: 295-305.

Solymos R. 1966: Állományszerkezeti és fatermési vizsgálatok Nyugat-dunántúli erdeifenyvesekben. Erdészeti kutatások 62(1-3): 47-66.

Solymos R. 1968: Új fatermési táblák a magyarországi lucfenyvesekre. Erdészeti kutatások 64(1-3): 7-30.

Solymos R. 1972: Az erdeifenyő-állományok fatermése Magyarországon. Erdészeti kutatások 67(1): 203-232.

Solymos R. 1973: A feketefenyő fatermése és állományszerkezeti viszonyai Magyarországon. Erdészeti kutatások 68(1): 155-174.

Solymos R. 1993: Új fatermési táblák erdeifenyőre. Erdészeti kutatások 82-83(2): 357-382.

Solymos R. 2000: Erdőfelújitás és -nevelés a természetközeli erdőgazdálkodásban. Mezőgazdasági Szaktudás Kiadó, Budapest.

Solymos R. 2013a: Hosszú lejáratú kísérletek az erdészettudományi kutatások területén l.. Erdészeti Lapok 148(2): 37-39.

Solymos R. 2013b: Hosszú lejáratú kísérletek az erdészettudományi kutatások területén II.. Erdészeti Lapok 148(3): $72-73$.

Somogyi Z. 1985: A kocsányostölgy hosszú lejáratú kísérleti területek felvételeinek számítógépes adattárolása és adatfeldolgozása. Erdészeti kutatások 76-77: 213-219.

Somogyi Z. 1986: Mikroszámítógép alkalmazása a faterméstani vizsgálatokban. Erdészeti kutatások 78: 261-264.

Somogyi Z. 1987: Mikroszámítógép alkalmazása a terepi adatgyüjtésben. Az Erdő 36(6): 277-279.

Somogyi Z. 1989: A változatosság, mint a természet egyik legfontosabb jelensége: gondolatok a fatermési táblák és függvények alkalmazásához. Az erdő 38(5): 214-218.

Sopp L. 1970: Fatömegszámítási táblázatok. Mezőgazdasági kiadó, Budapest.

Sopp L., Adorján J., Béky A., Birck O., Dérföldi A., Fadgyas K., Faragó S., Fekete Z., Gabnai E., Halupa L., Király L., Kiss R., Kovács F., Márkus L., Mendlik G., Palotás F., Somogyi Z., Solymos R., Szodfridt I., Tuskó L. 2013: Fatömeg számítási táblázatok. Negyedik, változatlan kiadás. Nemzeti Élelmiszerlánc-biztonsági Hivatal Erdészeti Igazgatóság, Budapest.

Sopp L., Adorján J., Béky A., Birck O., Faragó S., Fogarasi D., Harkay L., Kiss R., Kovács F., Márkus L., Mendlik G., Palotás F., Solymos R., Szodfridt I., Tuskó L. 1974: Fatömegszámítási táblázatok fatermési táblákkal, második, átdolgozott, bővített kiadás. Mezőgazda Kiadó, Budapest.

Veperdi G. 1995: Állományfelvételi adatok feldolgozása, feldolgozó algoritmusok Excel 5.0 táblázatkezelő programra, kezelés útmutató. Erdészeti Tudományos Intézet, Erdőművelési és Fatermési osztály, Budapest.

Érkezett: 2021. szeptember 03.

Közlésre elfogadva: 2021. október 20. 